\title{
A LETTER FROM THE EDITOR-IN-CHIEF
}

\author{
Dr. Kumkum Bharadwaj ${ }^{1 凹}$ \\ ${ }^{1}$ Professor (HOD) in Fine Arts, Maharani Laxmibai Girls P.G. College, Indore, India
}

\section{Dear readers and contributors,}

It gives me immense pleasure to inform that "ShodhKosh: Journal of Visual and Performing Arts" ISSN: 2582-7472 has been listed in the UGC-CARE list. It is a bi-annual peer-reviewed journal of visual and performing arts that publishes research papers in both Hindi and English. Our editorial members have also contributed significantly in this effort. As a result of this, we have been able to make the research fund one of the leading journals in the field of art, and I congratulate the editorial members and the publisher by appreciating them.

I would like to take this opportunity to express my gratitude to all the authors and reviewers whose contribution has made the journal reach this dimension. I would like to thank all the readers, contributors, writers, reviewers, and editorial members for all of you invaluable support and contribution.

This change marks the beginning of a new phase of development in the future as we want to establish "ShodhKosh: Journal of Visual and Performing Arts" ISSN: 2582-7472 Journal in the fields of art We are committed to striving for a more consistently high standard of publication, while maintaining our wide range of teachers that includes all of the faculty members. On a national and international level, we want to assist the journal in any way we can. Even as we reimagine ourselves in conventional fields of the arts, we will continue to publish theoretical, artistic, and empirical investigations of modern and contemporary art in all its aspects.

Over the years We have made several significant modifications to "ShodhKosh: Journal of Visual and Performing Arts" ISSN: 2582-7472 which will benefit all the researchers as well as we have done. ShodhKosh: Journal of Visual and Performing Arts (ShodhKosh) " ISSN: 2582-7472" is indexed on CrossRef, CrossMark, Google Scholar, Portico, Dimensions, PKP Preservation Network (PKP PN), Index Copernicus, PKP Index, so that all the papers published by us can be read nationally and internationally. We provide a unique DOI to each research article. The ShodhKosh is always progressing to support our commitment with well.

\section{प्रिय पाठकों एवं सहयोगकर्ताओं,}

मुझे यह सूचित करते हुए अत्यंत हर्ष का अनुभव हो रहा है "ShodhKosh: Journal of Visual and Performing Arts" ISSN: 2582-7472 UGC-CARE list में अनुक्रमिनित कर लिया गया है। यह एक अर्द्धवार्षिक पत्रिका है, जिसमें हिंदी व अंग्रेजी भाषा में शोध पत्रों का प्रकाशन किया जाता है। इस प्रयास में हमारे सम्पादकीय सदस्यों का भी महत्वपूर्ण योगदान रहा है। इसी के परिणाम स्वरूप हम शोध-कोष को कला के क्षेत्र में अग्रणी पत्रिकाओं में से एक बनाने में सफल हुए हैं, और मैं सम्पादकीय सदस्यों एवं प्रकाशक की सराहना करते हुए उन्हें बधाई देती हूँ।

में इस अवसर पर उन सभी लेखकों और समीक्षकों के प्रति आभार व्यक्त करना चाहती हूँ, जिनके योगदान से पत्रिका इस आयाम तक पहुँच पायी है। आप सभी के अमूल्य समर्थन व योगदान के लिए मैं सभी पाठकों, योगदानकर्ताओं, लेखकों, समीक्षकों, व सम्पादकीय सदस्यों को धन्यवाद प्रेषित करती हूँ।

यह परिवर्तन भविष्य में विकास के एक नए चरण की शुरुआत का प्रतीक है क्योंकि हम “ShodhKosh: Journal of Visual and Performing Arts" ISSN: 2582-7472 UGC-CARE list को कला के क्षेत्रों में मजबूती से स्थापित करना चाहते हैं, इस पत्रिका में कला के सभी शिक्षकों को शामिल करते हुए हम हमारे व्यापक दायरे को बनाये रखते हुए, हम प्रकाशन के निरंतर उच्च मानकों के प्रयास हेतु प्रतिबद्ध है। हम पत्रिका के राष्ट्रीय व अंतराष्ट्रीय समर्थन के लिए प्रयास करेंगे। कला के पारंपिक क्षेत्रों में अपने आप को सशक्त करते हुए आधुनिक और समकालीन कला के सभी आयामों के सैद्धांतिक, मौलिक और अनुभवजन्य अध्ययनों को प्रकाशित करना जारी रखेंगे।

विगत वर्षों से हमने "ShodhKosh: Journal of Visual and Performing Arts" ISSN: 2582-7472 UGC-CARE list में कुछ महत्वपूर्ण परिवर्तन किए है, जिससे सभी शोधकर्ताओं को लाभ मिले जैसे हमने ShodhKosh: Journal of Visual and Performing Arts (ShodhKosh) " ISSN: 2582-7472" की Indexing: CrossRef, CrossMark, Google Scholar, Portico, Dimensions, PKP Preservation Network (PKP PN), Index Copernicus, PKP Index पर की है, जिससे हमारे द्वारा प्रकाशित सभी शोधपत्र राष्ट्रीय व अंतराष्ट्रीय स्तर पर पढ़े जा सके। हमारे द्वारा सभी शोधपत्रों को स्वयं का DOI प्रदान किया जाता है। हमरी प्रतिबद्धता और सुधीजनों के सहयोगार्थ शोध-कोष निरंतर अग्रसर है।

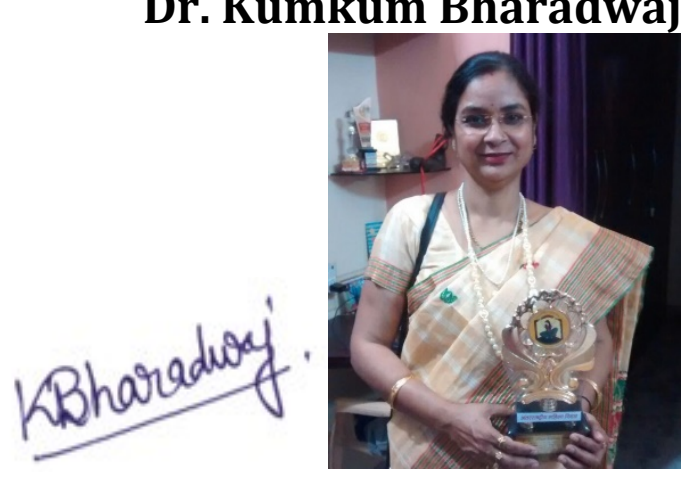

